Article

\title{
The Rise and Fall of Adult Community Education in Portugal
}

\author{
António Fragoso * and Sandra T. Valadas \\ Centre for Spatial and Organizational Dynamics (CIEO), University of Algarve, Gambelas Campus-Building 9, \\ Faculty of Economics, 8005-139 Faro, Portugal; svaladas@ualg.pt \\ * Correspondence: aalmeida@ualg.pt; Tel.: +351-289-800900
}

Received: 9 October 2018; Accepted: 12 November 2018; Published: 15 November 2018

\begin{abstract}
In this article, we intend to reflect on community education in Portugal. We analyse the background of the emergence of community education in the aftermath of the revolution of 1974, examine the main reasons that contributed to its dissemination, and identify its characteristics. We present a case study that illustrates both the rise and the fall of community education. The original investigation was a multiple case study. To gather information, we used non-structured interviews, informal conversations, observation, and document analysis. To continue the original investigation, we used biographical research, which allowed us to obtain more data on some of the key individuals and, at the same time, to improve our knowledge of the communities. Our results show that the period between 1985 and 2005 (roughly) constituted a very important period for community education. National phenomena, European funding programmes, and a notion of adult education that was very close to popular education aided civil society organisations to work with communities with interesting results in terms of social change. After 2005, changes in European social policy, neoliberalism affecting the power of civil society, and a new version of adult education (influenced by lifelong learning) partially caused the fall of community education.
\end{abstract}

Keywords: community education; adult education; lifelong learning; participation; popular education

\section{Introduction}

According to Tett (2010), community education's primary purpose is education within and for communities, which involves a blurring of traditional boundaries and an emphasis on education that grows out of people's experiences and the social interests that are generated within communities. In her opinion, although it is one of the newer forms of educational development, compared to formal education, the conceptual origins of community education stem from two quite older traditions. One comes from the radical working-class organisations, which developed popular educational activities through existing networks of support and solidarity. The second tradition is derived from the philanthropic provision of education in communities for poor, working-class adults and young people. However, Tett (2010) also notes that community education can be difficult to define as its focus varies over time in response to changing local, national, and global educational priorities. It includes a very wide range of educational practices that come from different traditions with a range of purposes, meanings, and intentions. Thus, many other forms of community intervention are strongly related to community education; for example, community development, community action, or community organisation. As the boundaries between them are sometimes difficult to trace, we can say that no clear definition of community education exists (Edwards et al. 2013). Hence, it is more important to understand the relationships between community, learning, and development than it is to discover a 
single label or concept (cf. Martin 2006). Analysing and discussing these connections will bring us closer to Tett's definition of community education as education within and for communities.

This was also the issue in Portugal, when community development and education arose in Portugal during the early 1980s. The first experiments made at the beginning of the decade approached territorial development that departed from adult education and the community's problems. Some years later, local development began to be conceptualised and implemented. For now, however, it is key to understand that community education has been created and developed by militant adult educators and not by a state initiative. Hence, it is not strange that the principles that inspired community education were, in a first phase, based on models close to popular education.

The main purpose of this article is to reflect on community education in Portugal, considering its emergence after the revolution of 1974 . We also examine the main reasons that contributed to its dissemination and identify some of its characteristics. Over two decades, community education experiences in Portugal were very common, even if other areas of adult education remained forgotten. However, there have been important changes in the last 10 years, so that today we can say that community education is in crisis. In this sense, we try to analyse the multiple motives of the rise and fall of community education in Portugal, based on data from a case study and the some macro-events that deeply affected adult education itself. To achieve our goal, we have investigated a multiple case study that started in 1985. The initial investigation reconstructed community education processes until 2003. From 2003 until today, we have maintained a research effort in order to understand and follow the events that occur in the same communities. This cumulative research experience allows us to have a unique perspective of the processes over time, so that we can analyse not only the inspiration for action, the philosophy, and the methodology, or changes in them across time, but also the changes, tensions, and contradictions that arose as a consequence. The case we present illustrates some of the strengths of the field of community education, and equally its recent problems, in connection with the major trends in adult education. Our first task is to shed some light on the wider context that framed adult community education experiences. It is important to understand the characteristics of both Portuguese adult education and community education at the time the action emerged and try to follow its evolution throughout time.

\section{Adult and Community Education in Portugal}

A political dictatorship existed in Portugal between 1926 and 1974. A very complex revolutionary process followed the military coup of April 1974. The social movements that arose created a swift radical process that caused a rupture in the typical capitalist framework (Santos 1985). Education in general and adult education in particular were at the core of the revolutionary process. Hundreds of small groups, cooperative societies, and local associations carried out a wide variety of non-formal activities, from basic adult education to cultural animation. This spontaneous popular movement assumed typical forms of mass mobilisation and direct democracy (Lima 1994b). For a while, there was central support to this movement (Melo and Benavente 1978; Norbeck 1983). However, the rebuilding of a capitalist state, made around a robust centralism (Barreto 1984), abandoned local initiatives (Lima 1994a), marking the end of the period of radical educational reforms (Stoer and Dale 1999), and displaced popular education to a marginal site of the education system (Silva 1990). Popular education groups, nevertheless, did not disappear from the Portuguese context. The lack of attention given to them by the state, paradoxically, provided the opportunity to avoid bureaucracy (Norbeck 1983), and, gradually, central initiatives began to be substituted by local community initiatives (Lima 1994b). Hence, it is not strange that when the political conditions changed, we found the tertiary sector acting strongly within community education and development, as we will see below.

In 1979, a Law was enacted that made the Government accountable for implementing a national plan to eliminate illiteracy, called the National Plan for Literacy and Basic Education of the Adults (PNAEBA). The commission that handled the task saw in it an opportunity to go further. The final plan intended to develop several areas of adult education, and to create institutions that could be 
the structural base of official adult education in Portugal. The PNAEBA consisted of seven different major programs. This was a very ambitious plan that nevertheless relied on a multitude of structural factors-including financial resources-that stood beyond the reach of the institutions responsible for its design and practical application (DGEP 1979). Within these conditions, it is not surprising that the programs of PNAEBA generally failed (DGEA 1986; Nogueira 1996). The exception to this failure was the programme of territorial approaches to development. In the beginning of the 1980s, several regional integrated plans for development were launched, with the aims of renewing the economic, social, and cultural local fabric, especially in isolated areas, and promoting 'bottom-up' methods, which allowed communities to be central actors in the processes.

The Mogadouro project was one example among others; however, it captured international attention. Briefly looking at some of the activities as reported by the European Council (Conselho da Europa 1983): from 1980 to 1982, about 22 courses of adult education were organised; health sessions in 55 villages; a number of professional training courses on various issues; support to local associations so that around 30 new popular associations were created; and an impressive number of cultural activities were organised, including cinema, theatre, library openings, new cooperatives, and museums. The European Council (Conselho da Europa 1983) stressed the participation in management of the processes; the social movements that the population built around the projects; the inductive role of the project; and, last but not least, the contribution to establish, in Portugal, new territorial approaches and strategic working methods in adult education. In summary, even if there is no doubt that the state did not support adult education, there were interesting results in community education and development. New theories and models of intervention arose (Nogueira 1996) as the pillars that would make a difference in the near future.

The 1986 reforms in the Law of education practically destroyed what was still trying to emerge. This reform ignored adult education as a whole (Gomes 1996), and all fields of social and educational intervention were practically absent (Comissão de Reforma do Sistema Educativo 1988). Even the territorial approaches to development and community education were discharged (Nogueira 1996). However, the same year of 1986 also marked Portugal's joining the European Economic Commission (EEC). This was crucial to obtain funding for a form of community intervention that otherwise would probably be as forgotten as many other dimensions of adult education in Portugal.

Portugal's joining the EEC (later the European Union, E.U.) in 1986 was one of the main triggers of community education, as several European funding programmes became available. Some of these programmes avoided state control and encouraged local groups to be the engines of projects using participatory methodologies. E.U. programmes allowed these groups to focus on the more deprived territories and, importantly, to design their projects from a bottom-up perspective that allowed the community's needs and problems to guide the action (Fragoso 2011). LEADER, for example, gave local groups the responsibility to coordinate community projects with little intervention from the state, but in cooperation with the local administrative bodies and a network of civil society organisations.

These conditions were crucial for civil society organisations to act in the community using popular education as an inspiration, as shown by the literature (Albino and Leão 1997; Henriques 1990; Melo 1988; Reis 1992). Action research methodologies were commonly used (Silva 1996), as was participatory research (Lima 1990). Deprived rural communities were the focus of most of these community projects. Some of the main characteristics of the community action, based in popular education, were the following (Fragoso 2009):

1. the teams of civil society organisations (sometimes, external to the communities) worked in cooperation with the people, helping them to organise their projects, but hoping that, in the near future, the community members would become independent and start their own initiatives. This meant that, in the first phases of a community education process, action was time-intensive and resources to support the population were always available.

2. The local interests, community problems, and culture constituted a departure point towards attempts to improve people's quality of life. The teams assumed that education has a political 
dimension, and studies such as Freire (1987) were a central inspiration. Adult education, in all its dimensions, was considered to be fundamental to a community, and not only in its more structured, almost formal aspects. Training was necessary to overcome literacy fragilities or support the development of new skills: fundamental, for example, to promote women's participation in local projects. However, the informal aspects of learning were equally considered to be determinants in all dimensions of community organisation. This includes promoting local social actors to unite around their interests (Fragoso 2014) or to build community structures that could assure their future, independent action.

3. The community's participation was indispensable. The fact that participation requires learning but has to be learnt by participating may pose some obstacles. Nevertheless, the circularity of participation may also be an advantage: its educating effects (Gutiérrez 1993) allow people to reach gradually increased levels of awareness, eventually creating truly conscientious processes (Freire 1997). In order to achieve this goal, community members should have the opportunity to participate in all of the phases of a process, namely identification of problems and community needs; planning and management; and control over decisions.

These principles were used in a number of Portuguese settings, when community education was on the rise, until the first few years of the new millennium. This was also valid for our case study, which we will describe and analyse briefly in the following sections.

\section{Methods}

To study the community education processes that went on in the community of the Abbey area (southern Portugal) until 2003, we designed a qualitative multiple case study (Yin 1993). The five cases we studied in the community all contributed to understanding the processes that those communities had created since 1985, along with a set of external social actors (the association that started the processes, and a number of institutions and individuals who had a part in those processes). We wanted to build a research process that was guided by a deep understanding of the events and phenomena in an interpretative way (Merriam 1998), so that we could investigate the meanings that people attribute to behavior, actions, and interactions with others (Denzin and Lincoln 2000). This research was designed to reveal the meaning that informs social life (Denzin and Lincoln 2000) and involved long periods of direct participation and observation (and the consequent building of a field diary), informal conversations, and about 70 non-structured interviews (individual and collective). The product was a set of descriptive data that we interpreted using rigorous and systematic methods of transcribing, coding, and analysis (Denzin and Lincoln 2000). To do so, we used content analysis. Through content analysis, we examined data in order to understand what they mean to people, what they enable or prevent, and what the information conveyed by them does (Krippendorff 2013). This type of analysis also allowed us to seek valid knowledge or practical support for actions and critique (Krippendorff 2013).

This research was only briefly suspended. We kept our presence in the community frequently and, over the years, informal conversations and some formal interviews were made. After 2010, we started to use biographical interviews, which allowed us to update our perspectives on the community. The biographical interviews were open, interviewee-led, and included highly detailed accounts of life experience (Merrill and West 2009). We also paid attention to the way people narrate and negotiate their own life stories, including the tone and structure (Alheit 2005), which is necessary to understand how experiences and choices are situated in a specific cultural context.

The use of biographical research was extremely helpful, especially because it opened the possibility for understanding an individual's evolution in a time where knowledge of the context was no longer a problem. The biographical interviews served to bring forth rich, subjective meanings, with the aim of building a collective history with a social meaning (Atkinson 2002) that was focused on the community. In fact, a life history has always been associated with a social characteristic, which can explain personal or specific traits of a certain time and space (Galvão 2005). The building of a social history is a type of biographical approach that we can easily find in the literature (e.g., Bertaux 1997; Vieira 1999). 
In this sense, biographical research allowed us to obtain more data to improve our knowledge of the communities.

\section{The Community Intervention's Context and Action (1985-2005)}

In 1985, the small team of the RADIAL/In Loco ${ }^{1}$ project started to work with the people from rural communities of southern Portugal. Our attention was focused on the community of Abbey, which is formed by a middle-mountainous area of about $200 \mathrm{Km}^{2}$. Abbey has a small central village that concentrates all services and about 52 different clusters of houses spread-out through the fields. Back in 1985 (INE 1998), the illiteracy rates were very high in Abbey and only a small percentage of the population had more than the basic schooling. Communication, public transport, schools, health centres, pharmacies, etc. were deficient or non-existent. The percentage of women working was low (around 10\%), and the unemployment among women was very high (26\%). Social and geographical isolation and the severe ageing of the population are central to an understanding of the territory.

What follows is a very short summary of the action that took place in this community until the beginning of the new millennium. The division of the action into three phases helps us to be clear.

1. The learning phase: During the period 1985-1991, In Loco team members were present on a daily basis in Abbey, supporting the local social actors. During these 6 years, the various community groups had the chance to access specific learning processes. We identified three different types of learning processes: first, in order to open infancy animation centres (four) and promote local employment, an in-service action-research training programme for pre-school local educators was created (the whole training programme lasted for three and a half years). Second, non-formal professional training programmes that targeted women's employment were created. These two-year programmes were structured around micro-production units that should function as such from the beginning of the training programme. Women had the opportunity to build micro-enterprises at the end of the training. Two of these courses took place in Abbey. Third, non-formal and informal learning processes were created that aimed at the organisation of informal groups; the construction of a new civic association; and the valuable lessons on participation that derived from those processes. The mediation done during this period by the In Loco team seemed crucial to ensure that a collective spirit in the community could grow. Six years might seem to be a long period. However, in 1991, the community members' autonomy was nothing more than embryonic and their dependence on In Loco was significant or even high. The team members' daily presence in the community made them valuable resources for every matter.

2. The endogenous phase (1991-1998): In 1991, In Loco team members had to stop being present on a daily basis in Abbey and the remaining communities. The association was appointed as the local action group of the LEADER programme, and they focused on the preparation of LEADER I applications. To understand the demands of such a task, In Loco gathered, organised, and presented to funding more than 150 projects to LEADER I (1991-1995) and close to 250 to LEADER II (1995-1999). While some were projects in the area of our case study (9 in LEADER I, 14 in LEADER II), the remaining projects were projects in about half of the region, and were for civil society organisations, local administrative bodies, such as City Halls, etc. In summary, this task required the full concentration and all of the skills of the In Loco team, which left little space for direct intervention in the community. For the community of Abbey, this fact meant that it would have to sever ties (of almost dependency) with In Loco and be forced to fully assume responsibility and autonomy, both for the ongoing processes and new initiatives to be planned. Two different characteristics marked this period. First, the ongoing experiences that were built in the past became mature and the results of educational processes became visible. These results were exceptionally noticeable regarding gender equity. Women began to assume

1 RADIAL $=$ Network to Support the Integrated Development of Algarve. This project lasted from 1985 to 1988 and in its wake emerged the civic association In Loco that continued the work that was initiated by Radial. 
leadership roles in the community for the first time in its history (for example, creating or participating in new associations), and there were clear signs of changing gender roles and emancipation. This was clear even from a political point of view; for example, women who participated in community action were candidates for local administration (Fragoso and Ollagnier 2016). These changes coexisted with the defence mechanisms of the community, as we had expected would happen, and conflict made its entrance into the public space. The mediation by In Loco did not exist anymore. Although some attempts at local mediation were present, there were no signs of positive effects deriving from it. Finally, also in 1991, a new institution started to intervene in Abbey: a Parish association. Although it was initially devoted to building services to support the older adults (a day-care service, in-home care, etc.), the Parish association soon began to act in various domains of the community.

Second, the community social actors were able, in this phase, in a collective manner and with good cooperation, to organise new activities. While some ideas benefited local producers (for example, the organisation of a regional fair where all of the producers could show and sell their products), some others had a cultural aim (for example, the creation of dancing and singing groups, a guitar school for kids, or an annual animation plan during local festivities). The new Parish association joined the remaining community groups and contributed accordingly (in common organisations, but also, for example, in building a small library, in making internet access free, and to provide tutoring to younger students).

In summary, although there were signs of community conflicts, in this phase Abbey seemed to be a more organised community that demonstrated solidarity. Social actors acquired experience through participation and gained a strong awareness that change was possible. The community seemed capable of, autonomously, taking care of its more frail citizens and reaching interesting patterns of change, either in social or cultural terms. The levels of cooperation between the different groups and individuals were interesting.

3. The dichotomic phase (1998-2005): In this phase, patterns of change included conflicting tendencies. On the one hand, the spontaneous activities of the community were kept at an interesting level and, in some organisations, there was still cooperation towards common goals. On the other hand, it was clear that some things were not evolving 'as expected'; for instance, the level of fragmentation within the core groups was growing. The local association that was created in the beginning of the action, with mediation by In Loco, did not unite all community members. Its action became connected only with the infancy animation centre. Other groups were created as a consequence: not because they were necessary, strictly speaking, but because the conflicts between the persons inside the core group led to the idea that the solution was to create a new group (formal or informal) that would be devoted only to specific aspects of the community's life. Conflicts then became clearer. The local equilibria of power were definitely moving. The Parish association seemed to dominate the local space of intervention in the community and cause some resentment among other individuals and groups. Mediation was simply absent. In this phase, the speed of change seemed to accelerate and unpredictability was a keyword. The modes of collective cooperation began to be replaced by the individual action of some local actors who gained prestige and centrality. Our analysis was that the modes of cooperation that made possible the positive changes that were made in the past were now threatened. Multiple sources of conflict (not just personal conflict) and unpredictability were key to explaining this feature (Fragoso and Emilio 2014).

The first few years of the millennium also brought new feelings to the local community that were related to the demographic dynamics and the visible results of the former interventions in the community. In fact, the militant discourses that stimulated the community to participate were that it was possible, locally, to create conditions (employment, economic opportunities, an improved education for children and adults, etc.) that stopped the migratory flows of the population, providing a better future for the young adults of the community. Despite the real achievements of almost two decades of community education and intervention, the demographic scenario was worsening. On average, the population of Abbey decreased by about $20 \%$ every ten years. The number of children 
was so low that the new state policies threatened the very functioning of the primary school and the pre-school centre. While, on the one hand, the community members felt that their lives had improved significantly over the last two decades, on the other hand that seemed to be not enough when faced with the strength of global phenomena, trends, and policies. The same reasoning was valid for opportunities for funding, which seemed to be rare. In short, the local climate was one characterised by fear, risk, and threats. Was community education on the decline?

Despite the fact that the local feeling was heading this way, we also have to look beyond the locality. Could adult education help? In the past, the general philosophy of lifelong education inspired adult educators. However, adult education was definitely changing.

\section{The New Adult Education or the Rise of Lifelong Learning}

The implementation of lifelong learning agendas was not sudden. The new meanings of lifelong learning became progressively clear. From the Lisbon Strategy, at least two key factors seem to be unavoidable (Fragoso and Guimarães 2010): that lifelong learning is crucial to improving the employability and the qualifications of workers and creating new programmes that allow the unemployed to access training; and to assure a flexible management of working time and job rotation through a variety of strategies. Policies now encourage individuals to build their own educational and training courses. Thus, lifelong learning has become an individual project. Individuals should "invest" in learning and in the creation and conversion of their human capital (Marginson 1997).

This shows the strength of the influence of economy over education, leading to the emergence of narrow visions of lifelong learning (Lima 2004). The adult education "that matters" is now the one that possesses instrumental application to the economy and the labour market, supporting the rhetoric of social competence and the making of workers that are able to adapt to structures and institutions that are in permanent change (Gustavsson 2002). In summary, lifelong learning has become a dominant reference in political discourses and within international organisations and U.E. state members, resulting in a transfer of responsibility to individuals for the building of their competences, which are demanded by the economy and the increasingly deregulated labour market (Lima 2012).

For the purposes of this article, this dominant vision of lifelong learning is important for various reasons. First, the "new" adult education is an instrument of the educational market that is marked by two important features: decreases in public funding and increases in the gap between learners who participate in the new educational programmes and ones who are excluded from those programmes (Lenz 1999). Second, the power of the neoliberal market over the state and the third sector lead to increasing difficulties in community education and intervention. In fact, the neoliberal state did not abandon regulation or control. At the same time as traditional forms of control may be vanishing, participative methodologies and community action have opened a new space in which civil society organisations are a fraction of the state (Santos 1990). This emerging partnership is based on the contracting of third sector organisations to work in the name of the state (making it each time more difficult to distinguish between the state and civil society). Contracting does question the basic principles of freedom and autonomy. The margins of independence of civil society organisations are defined, in each case or sector, by the particular rules imposed by the law and the technical instruments that control the conditions under which funding is given. Once organisations are caught in this culture of contract (Field 2006) they agree, even if implicitly, to be subjected to state regulation and control. Either way, there seems to be a permanent tension between civil society and the state agencies that frame it, constraint it, or facilitate its activities (Keane 1998). Civil society institutions are, therefore, becoming vulnerable. On the one hand, they are weakened by the vanishing policies of state social intervention (Andrade and Raquel 2007). On the other hand, they are weakened by the mechanisms of individualisation of the working institutions themselves (Autès 2003).

The impacts of lifelong learning and the new form of adult education are visible in the way people work or live in their communities. In the next section, we will try to show its connections to our case study. 


\section{The Impacts of Lifelong Learning over Community Education}

In the past, Portuguese adult education was seen as having four especially noticeable subfields (Canário 1999): literacies, sociocultural animation, professional training, and local development dynamics. Local development includes a significant number of community education interventions, such as the case study that we have been narrating and analysing. After the new millennium, we witnessed a shift in national policies and educational resources to fit the principles of lifelong learning. On the one hand, state agencies focused on adult education courses as a means to foster employability. On the other hand, the state created a system of recognition of prior learning around national frameworks of key competences. A network of adult centres emerged, aiming at a fast improvement of the qualifications of the population (Fragoso and Guimarães 2010). However, all of the remaining dimensions of adult education received no attention from policy. The humanistic dimensions of adult education, its connections to citizenship, community processes that might improve the population's quality of life, and even basic literacy, are but examples of forgotten dimensions of adult education.

Community education was always, in Portugal, promoted by civil society groups. These associations had to adapt to new conditions in order to survive, most of them by delivering services in the name of the state, and adhering to the neoliberal habit of contracting. The Portuguese laws fund civil society organisations in some sectors, corresponding to the ones that the state abandoned. This is especially noticeable in kindergartens and pre-school education, or in the older adults' care. However, little more is allowed of community organisations, especially if we think about bottom-up approaches that try to solve problems as they are felt by the community. This scenario has been made even worse by the gradual disappearance of the E.U. programmes, which, in the past, had funded thousands of community projects according to the population's needs. Together with the decrease in national funds, this fact has produced very difficult conditions for the third sector, which is now squeezed between the state and the market. The situation of In Loco-the association referred to in this study that has done amazing community work, both national and internal-might work as an example of these statements. The association grew when community education was on the rise, just as happened to a number of other civil society groups in the country. In the mid-1990s, approximately 40 persons worked in In Loco, supporting a number of interesting processes. Today, the association has 12 workers that depend financially solely on the projects applications they might gain.

The events and phenomena that characterise the Abbey communities after 2005 are illustrative. Our analysis reveals that three factors are crucial to an understanding of the situation:

1. Local civil society groups, suffering from the difficulties mentioned above, are incapable of creating new processes, apart from the ones that are state-subsidised. The day-care centre and the in-home services for older adults are still running. A new residential home is in place. Local employment depends partially on the older citizens' care, and the level of ageing of the population is still increasing. The Parish association is more central than ever in the local social networks. However, the activity of the remaining groups is only residual. Funding for most of the community activities seems now to be difficult to obtain and most of the European programmes are over. The only institution that can eventually obtain some resources to use is the local administration. The community suffered a hard blow.

2. The effects of the demographics and migration of the population. Children that are less than 14 years old are now rare in Abbey; at the same time, the number of citizens that are more than 65 years old is very high. The primary school was closed by the Ministry of Education (it did not reach the minimum required number of students), and the infancy animation centre was closed for the same reasons. The few children that live in the area have now to travel around $20 \mathrm{~km}$ to go to school. The reduction of the population affects local commerce. The women that had been working in the infancy centre (or some others who have been working in other sectors for a while) now find jobs taking care of older adults. 
3. The individualization of social life and the new opportunities for individual learning towards employability. We have stated above that, in the first few years of the new millennium, cooperation between groups and individuals was under threat. Conflicts from various sources, fragmentation of the core groups, the emergence of individuals that place prestige above cooperation, and the characteristics of the local social networks, were some of the motives that shattered cooperation. It soon became clear that the idea of fighting for the community with one voice was over.

The scenario we are depicting seems gloomy. However, it is important to say that this is not the end of the story. Biographical research reveals a key feature to our arguments in this article, as illustrated by the path of the women who, for more than 20 years, formed one of the micro-enterprises we mentioned above. For instance, the four women interviewed (Laura, Salome, Angel, and Maria), in 2003, registered in a centre recognising prior learning, and, after one year, they received a 9th grade certificate. In 2005, three of the women (Salome, Angel, and Maria) participated in a one-year library and archives training programme. They interned in a municipal library for some months; however, there was no chance of finding a permanent job there. In 2006 and 2007, the same three women participated in a programme that provided training in cooking and catering. After an internship of some months, Maria got a job in a new restaurant close to Abbey. Salome and Angel also tried to find employment in this field; however, neither found a permanent position. Angel is now working at the day-care centre in Abbey. As for Salome, she enrolled a three-year training programme on social and cultural animation. This programme gave Salome a 12th grade education. For some years, she was employed by the local administration to work in cultural animation. Laura started a new association that connects people who are engaged in handicrafts in the region. The association operates a small museum in a city $40 \mathrm{~km}$ away from Abbey and organises 20-22 small fairs during the three months in the summer. Laura frequently organises workshops and small training sessions. She is also responsible for managing three 'centres of rural world discovery'. These were originally primary schools. A project headed by In Loco transformed these buildings into small houses where a maximum of 12 people per house can be accommodated while they visit the area.

These examples are important. They show that these women have travelled along significant learning paths. Their individual trajectories indicate they were able to continue their education, taking advantage of the new lifelong learning processes at their disposal. Their participation in the educational processes that emerged in the mid-1980s was maybe a determinant in their will to go forward. The net results of the processes that started 30 years ago might not be ideal for the community, if we evaluate the issue in today's light. Nevertheless, there seems to be no doubt that education and learning were determinants in their individual life paths. We are, therefore, arguing that this illustrates both the advantages and limitations of lifelong learning. As individuals, we might use training in an instrumental way and be able to get a job and live a dignified life. The typical processes of lifelong learning of our societies mean little, however, to community dynamics, or to its ability to promote processes where social change is an aim.

\section{Discussion and Conclusions}

Community education processes in Abbey function as a thought-provoking case. At least in the first two decades (1985-2005), there was a dynamic within the community that, based in various educational processes, lead people to fight for the future they imagined to be possible. This meets the core purposes of community education, which involves a blurring of traditional boundaries and an emphasis on education that grows out of people's experiences and the social interests generated within communities. Community education is about encouraging and engaging people through life into learning that is based on what they are interested in (Tett 2010). Also, Edwards et al. (2013) note that disadvantaged communities often drawn upon forms of adult learning to enhance or transform their quality of life. Adult education-as it happened in our case-has played an important role in enabling and shaping the understanding, aspirations, and strategies that oppressed groups have pursued. In this respect, they claim that popular education is crucial. 
This seems to be key to an understanding of Abbey's processes during the phase of the rise of community education in Portugal. However, this was valid not only for the Abbey communities. In Silva (1996), we can find more than 30 cases in Portugal that share those basic characteristics. We are arguing that this rise of community education in Portugal was possible because of a conjunction of factors, namely: first, a European context that yielded a number of opportunities, through a variety of funding programmes, to community education and community action. This reminds us of the importance of appropriate work environments, so that community educators can concentrate effectively on their core educational tasks and develop people's competence through purposeful interaction: in the same sense, according to Bamber (2010), Habermas understands this to be a competence. Thus, the second crucial factor is a number of engaged adult educators who are willing to use popular education and participation to work with the people to give them the opportunity to engage in conscientious processes (Freire 1997). This was a direct product of the origins of the democratic Portuguese adult education, which was born in the aftermath of the social movements of the post-revolutionary period. Even if the state normalisation relegated popular education to a marginal position, the specific conditions of the 1980s in Portugal created an adequate environment the civil society to appear as a central actor again. Third, the processes of community education that are typical of this period show the importance of the sense of community and the ability to create non-paternalistic participative processes. Community participation and a sense of community are related to engagement and active involvement in issues that affect people's lives and influence the larger community (Talò et al. 2014). The case of Abbey shows this very clearly.

The events that took place in Abbey recently and that may illustrate the fall of community education have two main explanations. The first refers to the problems that emerged within the community. They have broken the sense of community through fragmentation and conflicts of various types; impeded the collaboration between the several groups of the community; questioned the value of community mediation; and compromised the dynamics of social change.

However, local factors are not the only factors that are involved. The same collapse has happened in a number of experiences all over the country. There are researchers that claim that community education is local and global, such as Bamber (2010). Others, such as Shevellar and Westoby (2018), pose key questions that are related to community development (a concept and practice deeply connected to community education): can community development contribute to solving local-global issues? In what measure is community development a useful, but humble, contributor to social change? Our opinion in this matter is based in the Abbey case analysis: community education can be a humble contributor to social change. However, at the same time, global issues deeply influence communities that cannot control phenomena that are created elsewhere. Some simple examples: we can create some jobs via community education; however, unemployment is generated by global policies and macro-processes that we cannot reach. Community education is also incapable of tackling ageing processes. It can deal with its consequences and try to attain a better quality of life for older adults, but no more than this.

The fall of community education in Portugal cannot, therefore, be attributed only to local factors. The changes in European social policies; the consequences of neoliberalism in the reduction of the power and autonomy of civil society in the face of the state and the market; and a new version of adult education, as influenced by lifelong learning, are examples of global trends that seem to us to be responsible for this state of affairs. In the past, the engagement of the local community in civic, organizational, and political affairs might have constituted a cornerstone of social research, practice, and action (Christens et al. 2016). The new versions of lifelong learning might be important for the economy, to the learning paths of individual learners, and to a presumptive neoliberal concept of employability. The fall of community education provides us with hard evidence: the new form of adult education seems not to include a central part of its historical heritage, which is connected to liberal and critical education. 
Author Contributions: Conceptualization, António Fragoso and Sandra T. Valadas; Formal analysis, António Fragoso; Investigation, António Fragoso; Methodology, António Fragoso; Resources, Sandra T. Valadas; Writing - original draft, António Fragoso and Sandra T. Valadas; Writing - review \& editing, António Fragoso.

Funding: This article was made possible by the national funding through the Foundation for Science and Technology (FCT), project UID/SOC/04020/2013.

Conflicts of Interest: The authors declare no conflicts of interest.

\section{References}

Albino, José Carlos, and Laura Leão. 1997. Desenvolver Desenvolvendo. Práticas e Pistas para o Desenvolvimento Local no Alentejo. Messejana: ESDIME.

Alheit, Peter. 2005. Stories and structures: An essay on historical times, narratives and their hidden impact on adult learning. Studies in the Education of Adults 37: 201-212. [CrossRef]

Andrade, António, and Franco Raquel. 2007. Economia do Conhecimento e Organizações sem Fins Lucrativos. Porto: Sociedade Portuguesa da Inovação.

Fragoso, António, and Lucio-Villegas Emilio. 2014. A mediação na comunidade e no desenvolvimento comunitário: tendências e potencialidades. Revista Lusófona de Educação 28: 23-37.

Fragoso, António, and Edmée Ollagnier. 2016. The involvement of women in training: A step towards an emancipatory community development process. In Researching and transforming adult learning and communities. Edited by Rob Evans, Ewa Kurantowicz and Emilio Lucio-Villegas. Rotterdam: Sense publishers, pp. 143-154.

Atkinson, Robert. 2002. The Life Story Interview. In Handbook of Interview Research. Context E Method. Edited by Jaber F. Gubrium and James A. Holstein. Thousand Oaks: Sage Publications, pp. 121-40.

Autès, Michel. 2003. As metamorfoses do trabalho social. In Os novos Desafios do Trabalho Social. Dinâmicas de um Campo Professional. Edited by Jean-Noel Chopart. Porto: Porto Editora, pp. 255-70.

Bamber, John. 2010. Developing competence in collegial spaces: exploring critical theory and community education. In Habermas, Critical Theory and Education. Edited by Mark Murphy and Ted Fleming. London: Routledge, pp. 97-110.

Barreto, António. 1984. Estado central e descentralização: antecedentes e evolução, 1974-1984. Análise Social 81-82: 191-218.

Bertaux, Daniel. 1997. Les Récits de Vie. Perspective Ethnosociologique. Paris: Nathan.

Canário, Rui. 1999. Educação de Adultos. Um Campo e uma Problemática. Lisboa: Educa.

Christens, Brian D., Paul W. Speer, and Andrew Peterson. 2016. Assessing community participation: comparing self-reported participation data with organizational attendance records. American Journal of Community Psychology 57: 415-25. [CrossRef] [PubMed]

Comissão de Reforma do Sistema Educativo. 1988. Documentos Preparatórios III. Reorganização do subsistema de educação de adultos. Technical Report. Lisboa: GEP/Ministério da Educação.

Conselho da Europa. 1983. O Projecto de Mogadouro. Pensar Educação 13: 3-44.

Denzin, Norman K., and Yvonna S. Lincoln, eds. 2000. Handbook of Qualitative Research. London: SAGE Publications.

DGEA. 1986. A educação de adultos 1980/1985. Actividades da DGEA. Ponto da Situação. Technical report. Lisboa: Ministério da Educação e Ciência.

DGEP. 1979. Plano nacional de alfabetização e educação de base dos adultos. Relatório de síntese. Technical report. Lisboa: Ministério da Educação.

Edwards, Richard, Sandy Sieminski, and David Zeldin, eds. 2013. Adult Learners, Education and Training. London: Routledge.

Field, John. 2006. Lifelong Learning and the Educational Order. Stoke: Trentham Books.

Fragoso, António. 2009. Desarrollo comunitario y educación. Barcelona: Diálogos.

Fragoso, António. 2011. Time goes by: an overview of local development trends in Portugal. In Between Global and Local: Adult Learning and Development. Edited by António Fragoso, Ewa Kurantowicz and Emilio Lucio-Villegas. Frankfurt Am Main: Peter Lang, pp. 119-31. 
Fragoso, António. 2014. Non-Formal and informal learning in the community: A case study in Northern Algarve (Portugal). In From Formal to Non-Formal: Education, Learning and Knowledge. Edited by Igor Z. Žagar and Polona Kelava. Newcastle upon Tyne: Cambridge Scholars Publishing, pp. 131-47.

Fragoso, António, and Paula Guimarães. 2010. Is there still a place for social emancipation in public policies? Envisioning the future of adult education in Portugal. European Journal for Research on the Education and Learning of Adults 1/2: 17-31. [CrossRef]

Freire, Paulo. 1987. Acção Cultural para a Liberdade. São Paulo: Editora Paz e Terra.

Freire, Paulo. 1997. Pedagogía del oprimido. Madrid: Siglo XXI de España Editores.

Galvão, Cecília. 2005. Narrativas em Educação. Ciência E Educação 2: 327-345.

Gomes, Carlos Alberto. 1996. Educação de adultos em seis áreas educativas do norte de Portugal: memórias de um curso. In Educação de adultos em Portugal. Situações e perspectivas. Edited by Comissão Organizadora. Coimbra: Comissão Organizadora das Jornadas de Educação de Adultos, pp. 239-53.

Gustavsson, Bernt. 2002. What do we mean by lifelong learning and knowledge? International Journal of Lifelong Education 21: 13-23. [CrossRef]

Gutiérrez, Francisco. 1993. Educação Comunitária e Desenvolvimento Sócio-Político. In Educação Comunitária e Economia Popular. Edited by Moacir Gadotti and Francisco Gutiérrez. São Paulo: Cortez Editora, pp. 23-33.

Henriques, José Manuel. 1990. Municípios e Desenvolvimento. Lisboa: Escher.

INE. 1998. Anuário Estatístico 1998. Região Algarve. Lisboa: Instituto Nacional de Estatística.

Keane, John. 1998. A sociedade civil. Lisboa: Temas e debates.

Krippendorff, Klaus. 2013. Content analysis. An introduction to its methodology, 3rd ed. London: SAGE Publications.

Lenz, Werner. 1999. Modern Trends in Adult Education. In Life Long Learning and Experience. Papers and Perspectives of the 1st International Summer School of the Graduate School in Lifelong Learning. Edited by Kirsten Weber. Roskilde: Roskilde University \& The Danish Research Academy, pp. 95-101.

Lima, Licínio C. 1990. Projecto Viana (1983-1988). Um ensaio de investigação participativa. Braga: Unidade de Educação de Adultos da Universidade do Minho.

Lima, Licínio C. 1994a. Fórum de educação de adultos (1987-1993). In Educação de Adultos. Forum I. Edited by Licínio C. Lima. Braga: Universidade do Minho, pp. 16-24.

Lima, Licínio C. 1994b. Inovação e mudança em educação de adultos. Aspectos organizacionais e de política educativa. In Educação de Adultos. Forum I. Edited by Licínio C. Lima. Braga: Universidade do Minho, pp. 59-73.

Lima, Licínio C. 2004. Adult education as social policy: reforming and post-reforming strategies in Portugal. In Perspectives on Adult Education in Portugal. Edited by Licínio C. Lima and Paula Guimarães. Braga: Universidade do Minho, pp. 17-37.

Lima, Licínio C. 2012. Educación Permanente en tiempos de crisis: volviendo a Freire, Gelpi e Illich. In Educación Permanente, vida Recebida y Cambio de Civilización. Edited by Marina Aparicio Barberán, Iolanda Corella Llopis and Paricao Aparicio Guadas. Xàtiva: Ediciones del Crec, pp. 41-62.

Marginson, Simon. 1997. Markets in Education. St. Leonards: Allen \& Unwin.

Melo, Alberto. 1988. O Desenvolvimento Local como Processo Educativo (impressões e opiniões auto-entrevistas). Cadernos a Rede 2: 58-63.

Melo, Alberto, and Ana Benavente. 1978. Educação Popular em Portugal (1974-1976). Lisboa: Livros Horizonte.

Merriam, Sharon B. 1998. Qualitative Research and Case Study Applications in Education. San Francisco: Jossey-Bass.

Merrill, Barbara, and Linden West. 2009. Using Biographical Methods in Social Research. London: SAGE.

Nogueira, António Correia. 1996. Para uma educação permanente à roda da vida. Lisboa: Instituto de Inovação Educacional.

Norbeck, Johan. 1983. Associações populares para o desenvolvimento. Pensar Educação 12: 5-55.

Reis, José. 1992. Os Espaços da Indústria. A regulação económica e o desenvolvimento local em Portugal. Porto: Edições Afrontamento.

Santos, Boaventura de S. 1985. Estado e sociedade na semiperiferia do sistema mundial: o caso português. Análise Social 87-89: 869-901.

Santos, Boaventura de S. 1990. O Estado e o direito na transição pós-moderna: para um novo senso comum sobre o poder e o direito. Revista Crítica de Ciências Sociais 30: 13-43.

Shevellar, Lynda, and Peter Westoby. 2018. The Routledge Handbook of Community Development Research. London: Routledge. 
Silva, Augusto S. 1990. Educação de adultos. Educação para o desenvolvimento. Rio Tinto: Edições ASA.

Silva, Maria Isabel. 1996. Práticas Educativas e Construção de Saberes. Metodologias da Investigação-acção. Lisboa: Instituto de Inovação Educacional.

Stoer, Stephen, and Roger Dale. 1999. Apropriações políticas de Paulo Freire: um exemplo da revolução portuguesa. Educação, Sociedade \& Culturas 11: 67-81.

Talò, Cosimo, Terri Mannarini, and Alessia Rochira. 2014. Sense of community and community participation: A meta-analytic review. Social Indicators Research 117: 1-28. [CrossRef]

Tett, Lyn. 2010. Community Education, Learning and Development, 3rd ed. Edinburgh: Dunedin Academic Press Ltd. Vieira, Ricardo. 1999. Histórias de Vida e Identidades. Porto: Edições Afrontamento.

Yin, Robert K. 1993. Applications of Case Study Research. Newbury Park: Sage Publications.

(C) 2018 by the authors. Licensee MDPI, Basel, Switzerland. This article is an open access article distributed under the terms and conditions of the Creative Commons Attribution (CC BY) license (http:/ / creativecommons.org/licenses/by/4.0/). 